\title{
主流に対して角度を有する 横越流堰の流量係数 DISCHAGE COEFFICIENT OF OBLIQUE SIDE WEIRS
}

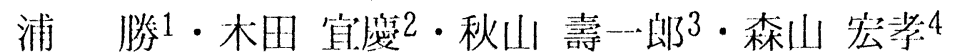 \\ Masaru URA, Yoshinori KITA, Juichiro AKIYAMA and Hirotaka MORIYAMA \\ 1 1 正会員 工博 九州工業大学教授 工学部建設社会工学科（T804-8550 北九州市戸烟区仙水町1-1） \\ 2学生会員 九州工業大学大学院 工学砍究科博上前期深程（问上） \\ 3正会員 Ph.D. 九州工業大学助教授 工学部建設社会工学科（同上） \\ 4非会員 工学部設計生産工学科（同上）
}

\begin{abstract}
An investigation of side-weirs, used as a diversion structures in rivers and canals, is presented. Most commonly, the side-weirs are aligned parallel to the direction of flow in the parent canal, giving an offtake angle, $\theta$ of 90 degrees. However, this study investigates performance of oblique side-weirs, that offtakes at an angle less than 90 degrees. Discharge coefficients for oblique weirs are obtained theoretically and experimentally as functions of off-take angle, $\theta$, Froude number in the parent channel and weir geometry. It is found that a high value of discharge coefficient can be maintained when $\theta$ lies between 60 and 80 degrees. A side weir with $\theta$ equal to 70 degrees is selected for further study with improved frontal apron and approach wall. It is concluded that the value of discharge coefficient can be further increased for a wide range of high Froude numbers through these improvements.
\end{abstract}

Key Words : side-weir, oblique side-weir, discharge coefficient,

\section{1.はじめに}

都市内を流れる河川は流域内の開発が進められる に従って降雨の流出係数が大きくなり,ビーク流量 が河道計画時点よりも大きくなっている.さらに最 近,雨が局所的に短時間に多量に降る傾向にあり,都 市河川の氾濫が多発している.この対策の1つとして 洪水調節池がある.これは都市河川の河道拡幅が困 難な場合に,それより上流において河道側方に横越 流堰を設置し, 流下能力を上まわる流量分を調節池 に一時的に貯留し,減水期に河道に戻すものである.

一般に横越流揠は,堰の法線方向と河道主流方向 となす角（これを堰角度 $\theta$ と呼ぶ）が $90^{\circ}$ に設置さ れる.河道側壁に設けられる横越流堰の流量算定式

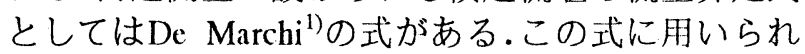
る流量係数 $C_{M}$ についてはSubramanya \& Awasthy ${ }^{2}$ が 系統的な実験を行い,堰上流端における主流のFroude 数 $F_{1}$ の関数で表されることを示しているこれによ ればFroude数が 0.1 から0.6に増加すれば流量係数は 0.611から0.45に減少する.このことは河道の出水時 は流量が増加しFroude数が增加するため洪水ピーク
時に越流量を確保することが難しく,かつ,越流堰を 長くとらねばならなくなる。浦ら は側壁勾配 $m$ を持 つ台形断面水路に設けられた横越流堰に関して実験 を行い,越流量算定式と流量係数について調べた。そ の結果, 流量係数は堰上流端のFroude数の増加に伴 い減少すること,その関係式が側壁勾配 $m$ の関数と して表されることを示し, $m=0$ の矩形断面水路の場 合はSubramanya \& Awasthyの結果とほぼ一致するこ とを示した.河道に設けられる横越流堰の流量係数 が,主流のFroude数に依存することはSubramanya \& Awasthyによれば堰を越流する流れが主流によって 引きずられ斜めに流下し有效越流長が減少するため であるとした。

一方, 越流状況の観察から,堰上流端における流れ が側壁のため剥離していること,および堰下流端に おいては流れが側壁に衝突して越流を阻害している ことがわかった.このことを考慮し,本研究では越流

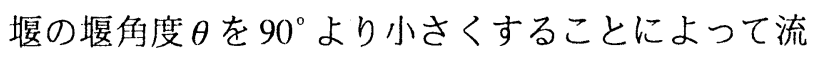
量係数がどのように変化するかを調べ, 堰角度 $\theta$ ご とに流量係数を定式化した.

さらに本研究では, Froude数のより広い範四で流 
量係数が高い値を持つための改良を行つた。それは 堰角度 $70^{\circ}$ の場合において, 堰前面に斜面を取り付け ること,および堰上流側の剥離を解消するために河 道側壁を曲面とすることである。このことにより流 量係数が大幅に改善することを示した。

\section{2. 理論的考察}

ここで考える横越流愃は水路床勾配 $i_{0}$, 水路幅 $B$ の矩形断面水路の侧壁に,図-1に示すように堰天端 の法線方向が主流方向に対して何度 $\theta$ (本研究では

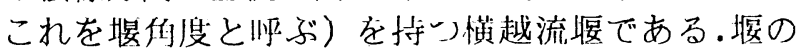
上流端断面を(1)-(1)'，下流端断面を(2)-(2)'とし， (1)-(2)区間を垵区間長 $L$ とする.横断面(1)-(1) -(1)" を図一2に示す.揠高を $W$ とする.堰角度 $\theta=90^{\circ}$ の場 合は(1)”が(1)'に一致し, 図-1の(1)'-(2) の部分に 堰があることになり通常の横越流堰となる.

主水路の流下方向に $x$ 軸をとり, $x$ における水深 を $y$,断面積を $A$, 径深を $R$, 流量を $Q$ とする.堰区 間の単位幅流出量を $q$ とすると, 連続の式は次式と なる。

$$
-d Q / d x=q
$$

水路床に沿う比エネルギーを $E$ で表す。

$$
E=y+\frac{Q^{2}}{2 g B^{2} y^{2}}
$$

堰区間(1)-(2)に運動量の定理を適用すると,横越 流を伴う場合の水面形方程式が得られる.

$$
\frac{d y}{d x}=\frac{i_{0}-\frac{Q^{2}}{C_{h}{ }^{2} R \Lambda^{2}}+\frac{\beta Q q}{g A^{2}}}{1-\frac{\beta Q^{2} B}{g \Lambda^{3}}}
$$

ただし, $C_{h}$ はChézyの流速係数, $\beta$ は運動量補正係数 である.上式において,水路床勾配 $i_{0}$ がそれほど急で ない場合は分子の第1項と第2項はほぼ等しい.さら に矩形断面水路を考えて, $\beta=1.0$ と近似すると,式 (3)は次のように簡略化される.

$$
\frac{d y}{d x}=\frac{Q q y}{g B^{2} y^{3}-Q^{2}}
$$

次に堰区間の単位幅越流量 $q$ について考える.堰 角度 $\theta$ をもつ堰に接近する流れは,図-3に示すよう に主流速 $u$ に引きずられるため図中の(3)点において 堰角度 $\theta$ とは買なり,主流方向と角度 $\varphi$ をなす $v_{j}$ と 仮定する.すなわち

$$
\cos \varphi=u / v_{j}
$$

主流と分かれた流れはその觕度 $\varphi$ を保持し，堰上の 点(4)を流速 $v_{k}$ で越流するとする.この $v_{k}$ の大きさは (3)点で持つ比エネルギーの一部によって決定される として次のようにおく.

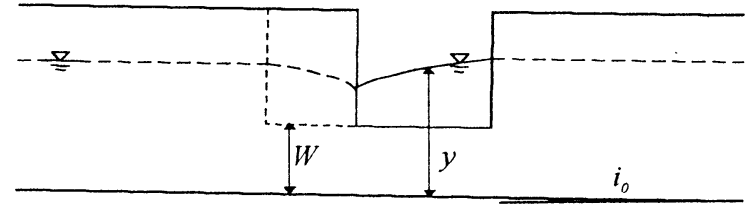

（側面図）

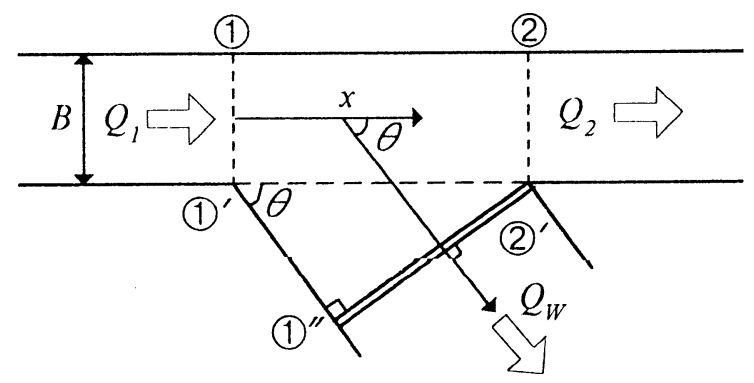

図-1 堰角度 $\theta$ の横越流㘿(平面図)

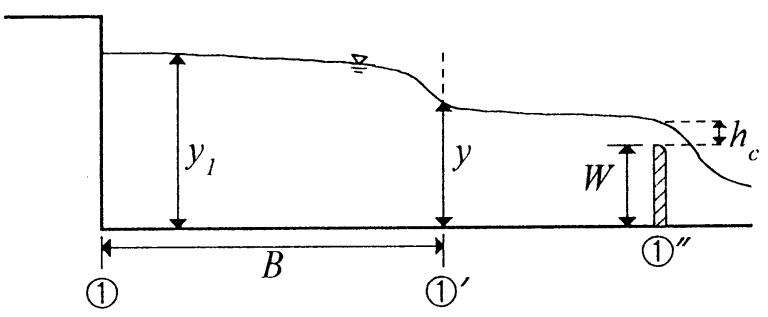

図-2 横断面図(図-1の断面(1)-(1)' -(1)” )

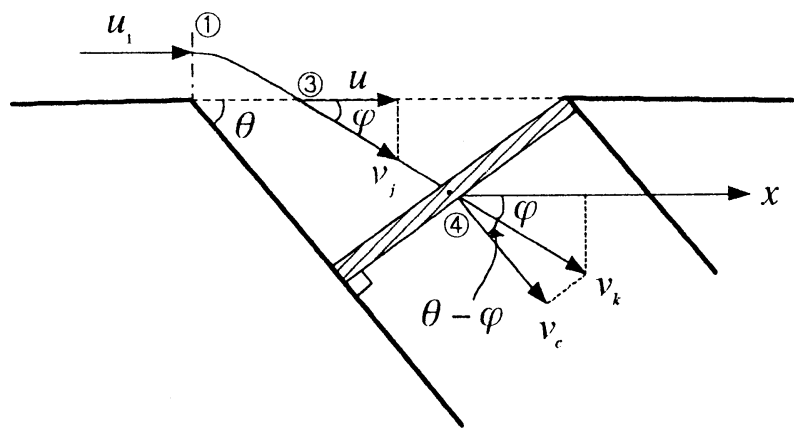

図-3 堰近傍の流速と流向

$$
y+\frac{\alpha_{0} u^{2}}{2 g}=h_{c}+W+\frac{v_{k}^{2}}{2 g}
$$

ここに $\alpha_{0}$ は主流の流速水頭の奇与率, $W$ は堰高, $h_{c}$ は越流水深である.堰上では限界流となるとして

$$
v_{k}^{2} / g h_{c}=1.0
$$

の条件を式(6)に用いると

$$
\begin{array}{r}
h_{c}=\frac{2}{3}\left(y-W+\frac{\alpha_{0} u^{2}}{2 g}\right) \\
v_{k}{ }^{2}=\frac{2}{3} g\left(y-W+\frac{\alpha_{0} u^{2}}{2 g}\right)
\end{array}
$$

が得られる.堰角度 $\theta$ の法線方向の流速成分 $v_{c}$ は

$$
v_{c}=v_{k} \cos (\theta-\varphi)
$$

と表されるから堰区間の単位幅流量 $q$ は流量係数を Cとして

$$
q d x=C v_{c} h_{c} d x \sin \theta
$$


となる.式(11)に式(8),(9),(10)を代入すると $q=C v_{k} h_{c} \cos (\theta-\varphi) \sin \theta$

$=C \sqrt{\frac{2}{3} g\left(y-W+\frac{\alpha_{0} u^{2}}{2 g}\right)} \cdot \frac{2}{3}\left(y-W+\frac{\alpha_{0} u^{2}}{2 g}\right) \cos (\theta-\varphi) \sin \theta$ $=\frac{2}{3} \sqrt{2 g}(y-W)^{\frac{3}{2}} \frac{C}{\sqrt{3}}\left[1+\frac{\alpha_{0} u^{2}}{2 g(y-W)}\right]^{\frac{3}{2}} \cos (\theta-\varphi) \sin \theta$

が得られる.ここで上式において

$$
C_{M}=\frac{C}{\sqrt{3}}\left[1+\frac{\alpha_{0} u^{2}}{2 g(y-W)}\right]^{\frac{3}{2}} \cos (\theta-\varphi) \sin \theta
$$

とおけば,式(12)は形式的に次式で表される.

$$
q=\frac{2}{3} \sqrt{2 g}(y-W)^{\frac{3}{2}} C_{M}
$$

式(4)に式(2), (14)を代入すると次式を得る.

$$
\frac{d y}{d x}=\frac{4}{3} \frac{C_{M}}{B} \frac{\sqrt{(E-y)(y-W)^{3}}}{3 y-2 E}
$$

ここで, $C_{M}$ を $x$ に関して一定とおけば,式(15)が断 而(1)-(2)閣で積分可能であり, 次式を得る1).

$$
x_{2}-x_{1}=L=\frac{3}{2} \frac{C_{M}}{B}\left(\phi_{2}-\phi_{1}\right)
$$

$$
\phi_{i}\left(y_{i}, E_{i}\right)=\frac{2 E_{i}-3 W}{E_{i}-W} \sqrt{\frac{E_{i}-y_{i}}{y_{i}-W}}-3 \tan ^{-1} \sqrt{\frac{E_{i}-y_{i}}{y_{i}-W}}
$$

ここに, $i=1,2$ は断面(1)，(2における値を示す. 式(16),(17)はDe-Marchiの式と呼ばれる2).

本研究では堰角度 $\theta$ をもつ横越流堰であり,流量係 数 $C_{M}$ は式(13)で規定されることが予想される.これ を次章で示す方法で実験的に調べたが,いま少し理 論的考察を行っておく.

式(13)において[]内の項を次のように表示する.

$$
\begin{gathered}
{\left[1+\frac{\alpha_{0} u^{2}}{2 g(y-W)}\right]^{\frac{3}{2}}=\left[1+\frac{\alpha F_{1}^{2}}{2(1-\eta)}\right]^{\frac{3}{2}}} \\
F_{1}{ }^{2}=u_{1}{ }^{2} / g y_{1}=Q_{1}{ }^{2} / g B^{2} y_{1}{ }^{2} \\
\eta=W / y_{1} \\
\gamma=u / u_{1} \\
\alpha=\alpha_{0} \gamma^{2} \cdot(1-\eta) /\left(y / y_{1}-\eta\right)
\end{gathered}
$$

とした.式(13)中の角度 $\varphi$ は式(5)で定義したが,これ を次のように推定する.すなわち越流する流れが主 流から分かれる直前において図-3の(1)点と(3)点の比 エネルギーが等しいとして

$$
y_{1}+\frac{u_{1}^{2}}{2 g}=y+\frac{v_{j}}{2 g}
$$

とおく。流れが分かれるときは(3)点において支配断 面となると考えると

$$
v_{j}^{2} / g y=1.0
$$

とおける.これを式(23)に代入すると次式を得る.

$$
v_{j}^{2}=\frac{2}{3} g\left(y_{1}+\frac{u^{2}}{v_{j}^{2}}\right)
$$

式(5)に式(25)を代入して, $\cos \varphi$ は

$$
\begin{aligned}
\cos \varphi=\frac{u}{v_{j}}=\left(\frac{u^{2}}{v_{j}{ }^{2}}\right)^{\frac{1}{2}} & =\sqrt{\frac{u^{2}}{\frac{2}{3} g\left(y_{1}+\frac{u_{1}{ }^{2}}{2 g}\right)}} \\
& =\sqrt{\frac{3 \gamma^{2} F_{1}{ }^{2}}{2+F_{1}{ }^{2}}}
\end{aligned}
$$

となる.よって,式(13)は $C=1.06$ とすると

$$
\begin{gathered}
C_{M}=0.611\left[1+\frac{\alpha F_{1}^{2}}{2(1-\eta)}\right]^{\frac{3}{2}}\left(\cos \theta \sqrt{\frac{3 \gamma^{2} F_{1}{ }^{2}}{2+F_{1}^{2}}}\right. \\
\left.+\sin \theta \sqrt{1-\frac{3 \gamma^{2} F_{1}^{2}}{2+F_{1}^{2}}}\right) \sin \theta
\end{gathered}
$$

と表せる.上式において $\left[1+\frac{\alpha F_{1}^{2}}{2(1-\eta)}\right]^{3 / 2}$ 内の第2項は 接近流速の影響を表している.これが堰角度,前面形 状などにより,無視できる場合には式(27)は次式

$C_{M}=0.611\left(\cos \theta \sqrt{\frac{3 \gamma^{2} F_{1}^{2}}{2+F_{1}^{2}}}+\sin \theta \sqrt{1-\frac{3 \gamma^{2} F_{1}^{2}}{2+F_{1}^{2}}}\right) \sin \theta$

に近似できる.さらに式(28)において $\theta=90^{\circ}$ のとき, $\cos \theta=\cos 90^{\circ}=0, \sin \theta=\sin 90^{\circ}=1$ より

$$
C_{M}=0.611 \cos (\theta-\varphi) \sin \theta=0.611 \sqrt{1-\frac{3 \gamma^{2} F_{1}^{2}}{2+F_{1}^{2}}}
$$

となり, $\gamma=1.0$ とおけばSubramanya \& Awasthy ${ }^{2)}$ の式 と一致する.

\section{3．実験装置および実験方法}

本実験に用いた水路は長さ $600 \mathrm{~cm}$, 水路の底面幅 $B=11.5 \mathrm{~cm}$, 深さ $25 \mathrm{~cm}$, 水路床勾配 $i_{0}=1 / 833$ の矩形断面 水路である.図一にに示したように,水路の上流より $x=350 \mathrm{~cm}$ の地点を断面(1)とし,これより下流に堰区 間 $L=15 \mathrm{~cm}$ をりこれを断面(2)とした.断面(1)-(2)の 水路右岸側に堰角度 $\theta$ を持つよう越流堰を設置し た. $\theta$ を $40^{\circ}, 50^{\circ}, 60^{\circ}, 70^{\circ}, 80^{\circ}, 90^{\circ}$ の6段階に変え

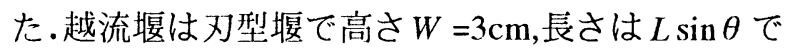
ある。それそれの $\theta$ に対しては堰上流端水深を $y_{1}=$ $5.0,7.0,9.0 \mathrm{~cm}$, 堰上流端Froude数 $F_{1}=0.4,0.5,0.6,0.7$, 0.8 と系統的に変化させた.堰始端および垵終端の水 深 $y_{1} ， y_{2}$ は超音波変位計を用いて測定した.堰上流 
端流量 $Q_{1}$ は四角堰を越える越流水深をもとに, 堰下 流端流量 $Q_{2}$ は量水枡の水位上昇速度を容量式波高 計を用いることで算出した。越流量 $Q_{W}$ は $Q_{W}=Q_{1}-Q_{2}$ として求めた.

実験の種類は図-1に示すように堰角度 $\theta$ を変えた 場合をTypeAとよぶ.また第 5 章で示すように $\theta=70^{\circ}$ のときに堰前面に斜面を取り付けた場合をTypeFと よび,さらにTypcFの 70の堰上流側側壁を曲面とし た場合をTypeGとする.

\section{4. 実験結果}

表-1にType $\Lambda$ の場合の $\theta=70^{\circ}, 90^{\circ}$ およびTypeFの $70^{\circ}$,TypeGの場合の $70^{\circ}$ の垁験絬果を示す.TypeAの $\theta=40^{\circ}, 50^{\circ}, 60^{\circ}, 80^{\circ}$ に関しても同様な結果を得た.

まず,Type $\Lambda$ の場合の流量係数 $C_{M}$ と Froudc数 $F_{1}$ の関係を堰角度 $\theta$ ごとに図-4に示した.同図には相

\section{表-1 水理諸量}

\begin{tabular}{|c|c|c|c|c|c|c|c|}
\hline $\begin{array}{c}\theta \\
\left({ }^{\circ}\right)\end{array}$ & $\begin{array}{c}y_{1} \\
(\mathrm{~cm})\end{array}$ & $\begin{array}{c}y_{2} \\
(\mathrm{~cm})\end{array}$ & $\begin{array}{c}Q_{1} \\
(\mathrm{cc} / \mathrm{s})\end{array}$ & $\begin{array}{c}Q_{2} \\
(\mathrm{cc} / \mathrm{s})\end{array}$ & $\begin{array}{c}Q_{W} \\
(\mathrm{cc} / \mathrm{s})\end{array}$ & $F_{1}$ & $C_{M}$ \\
\hline \multirow{14}{*}{$\begin{array}{c}90 \\
\text { Typen }\end{array}$} & 5.01 & 5.24 & 1600 & 792 & 808 & 0.397 & 0.545 \\
\hline & 5.00 & 5.26 & 2060 & 1216 & 844 & 0.512 & 0.483 \\
\hline & 5.01 & 5.37 & 2437 & 1605 & 8.32 & $0.6(14$ & 0.428 \\
\hline & 5.02 & 5.50 & 282.3 & 1976 & 847 & 0.698 & 0.425 \\
\hline & 4.99 & 5.74 & 3219 & 2348 & 871 & 0.802 & 0.383 \\
\hline & 7.02 & 7.32 & 2658 & 499 & 2159 & 0.397 & 0.528 \\
\hline & 7.02 & 7.46 & 3355 & 1210 & 2145 & $0.5(1) 2$ & $(0.480)$ \\
\hline & 7.03 & 7.61 & 3991 & 1847 & 2144 & 0.595 & 0.435 \\
\hline & 7.00 & 7.81 & 4666 & 2384 & 2282 & 0.701 & 0.416 \\
\hline & 6.99 & 7.99 & 5325 & 3100 & 2225 & 0.801 & 0.350 \\
\hline & 9.01 & 9.49 & 4860 & 1040 & 3820 & 0.499 & 0.481 \\
\hline & 9.00 & 9.74 & 5877 & 2181 & 3696 & 0.604 & 0.422 \\
\hline & 9.00 & 10.01 & 6827 & 2990 & 3837 & $0.7(1) 2$ & 0.395 \\
\hline & 8.99 & 10.23 & 7809 & 4082 & 3727 & 0.805 & 0.331 \\
\hline \multirow{14}{*}{$\left|\begin{array}{c}70 \\
\text { IypeA }\end{array}\right|$} & 4.99 & 5.21 & 1612 & 734 & 878 & 0.402 & 0.585 \\
\hline & 4.98 & 5.25 & 2034 & 1099 & 935 & 0.508 & 0.542 \\
\hline & 4.98 & 5.36 & 2433 & 1418 & 1015 & 0.608 & 0.518 \\
\hline & 5.01 & 5.60 & 2811 & 1688 & 1123 & 0.697 & 0.528 \\
\hline & 5.00 & 5.79 & 3214 & 2029 & 1185 & 0.799 & 0.483 \\
\hline & 7.01 & 7.28 & 2687 & 418 & 2269 & 0.403 & 0.554 \\
\hline & 7.00 & 7.40 & 3292 & 987 & 2305 & 0.493 & 0.521 \\
\hline & 6.98 & 7.59 & 3989 & 1647 & 2342 & 0.601 & 0.481 \\
\hline & 6.99 & 7.84 & 4686 & 2217 & 2469 & $0.7(1) 4$ & 0.450 \\
\hline & 6.99 & 8.10 & 5353 & 2813 & 2540 & 0.804 & 0.405 \\
\hline & 9.01 & 9.46 & 4834 & 871 & 3963 & 0.497 & 0.501 \\
\hline & 9.00 & 9.58 & 5828 & 1811 & 4017 & 0.600 & 0.456 \\
\hline & 8.98 & 9.83 & 6820 & 2721 & 4099 & 0.703 & 0.413 \\
\hline & 9.01 & 10.16 & 7801 & 3778 & 4023 & 0.802 & 0.359 \\
\hline \multirow{12}{*}{$\begin{array}{c}70 \\
\text { TypeF }\end{array}$} & 4.99 & 5.24 & 1582 & 575 & 1007 & 0.395 & 0.681 \\
\hline & 5.01 & 5.38 & 2007 & 852 & 1155 & 0.493 & 0.699 \\
\hline & 5.00 & 5.45 & 2392 & 1141 & 1251 & 0.594 & 0.661 \\
\hline & 5.01 & 5.63 & 2797 & 1423 & 1374 & 0.693 & 0.636 \\
\hline & 5.01 & 5.81 & 3208 & 1751 & 1457 & 0.796 & 0.573 \\
\hline & 7.00 & 7.45 & 3299 & 6.37 & 2662 & 0.495 & 0.610 \\
\hline & 6.99 & 7.61 & 3990 & 1213 & 2777 & 0.599 & 0.571 \\
\hline & 6.99 & 7.81 & 4664 & 1753 & 2911 & 0.701 & 0.530 \\
\hline & 7.00 & 8.15 & 5353 & 2457 & 2896 & 0.804 & 0.465 \\
\hline & 9.00 & 9.68 & 5840 & 1268 & 4572 & 0.601 & 0.530 \\
\hline & 9.00 & 10.02 & 6792 & 1979 & 4813 & 0.700 & 0.506 \\
\hline & 9.02 & 10.29 & 7776 & 2873 & 4903 & 0.799 & 0.449 \\
\hline
\end{tabular}

\begin{tabular}{|c|c|c|c|c|c|c|c|}
\hline \hline & 4.99 & 5.33 & 1616 & 615 & 1001 & 0.403 & 0.693 \\
\cline { 2 - 8 } & 4.99 & 5.46 & 2021 & 888 & 1133 & 0.503 & 0.717 \\
\cline { 2 - 8 } & 5.01 & 5.65 & 2409 & 1082 & 1327 & 0.597 & 0.750 \\
\cline { 2 - 8 } & 5.00 & 5.78 & 2820 & 1264 & 1556 & 0.700 & 0.753 \\
\cline { 2 - 8 } 70 & 5.01 & 5.97 & 3208 & 1400 & 1808 & 0.796 & 0.739 \\
\cline { 2 - 8 } & 7.00 & 7.52 & 3325 & 395 & 2930 & 0.499 & 0.671 \\
\cline { 2 - 8 } Type & 7.00 & 7.70 & 3993 & 856 & 3137 & 0.598 & 0.653 \\
\cline { 2 - 8 } & 7.00 & 7.94 & 4655 & 1272 & 3383 & 0.698 & 0.632 \\
\cline { 2 - 8 } & 6.99 & 8.09 & 5299 & 1747 & 3552 & 0.797 & 0.578 \\
\hline & 9.01 & 9.85 & 5841 & 618 & 5223 & 0.600 & 0.615 \\
\cline { 2 - 8 } & 8.99 & 10.11 & 6807 & 1309 & 5498 & 0.702 & 0.588 \\
\cline { 2 - 8 } & 8.99 & 10.46 & 7815 & 1844 & 5971 & 0.805 & 0.566 \\
\hline
\end{tabular}

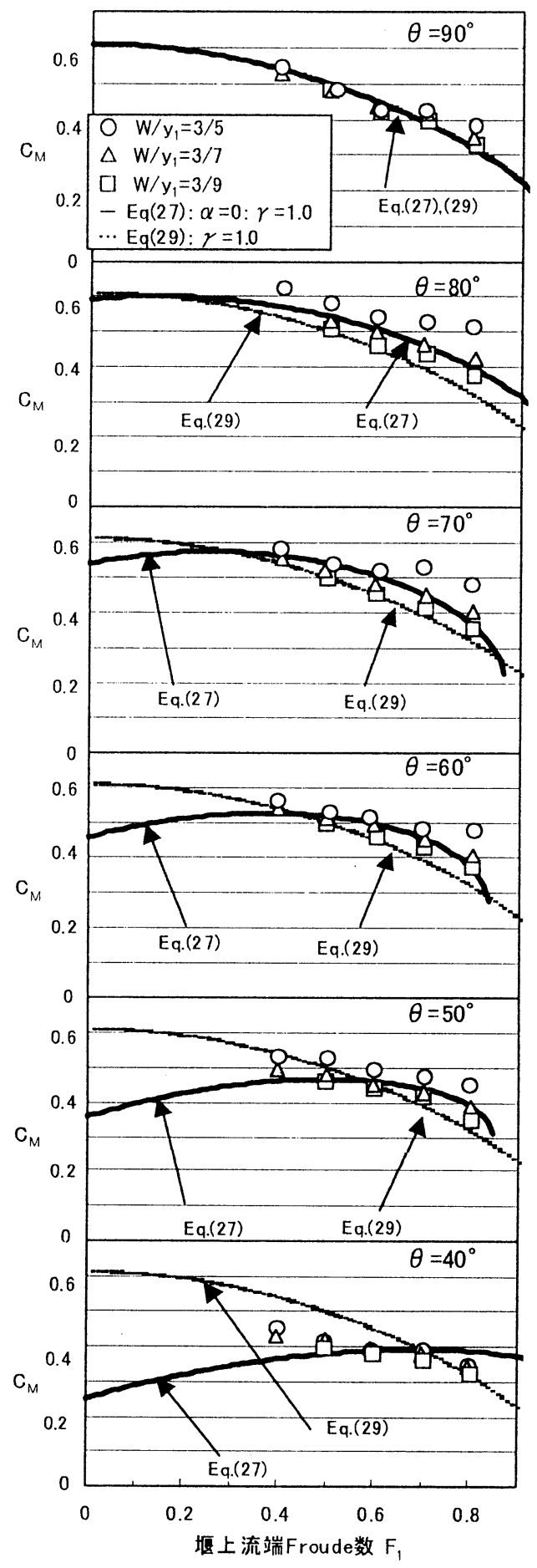

図-4 TypeAにおける堰上流端Froude数 $F_{1}$ と 流量係数 $C_{M}$ の関係 
対堰高 $W / y_{1}$ をパラメータとして記号を変えて示し ている。

図中の太実線はいずれも式(27)において $\alpha=0, \gamma=1.0$ としたものである.図中の細線は $\theta=90^{\circ}$ の式(29)において $\gamma=1.0$ とした Subramanya \& Awasthy ${ }^{2)}$ の式である.比較のために式(29)は全ての $\theta$ の曲線に記入した.同図より流量係数の実験值は $\theta=90^{\circ}$ のとき, $W / y_{1}$ による差は認められず,いずれ も $\alpha=0, \gamma=1.0$ とした式(27)でほぼ近似される. $\theta$ が $90^{\circ}$ より小さくなると, 図中○印で示した $W / y_{1}=3 / 5$ の実験值が $W / y_{1}=3 / 7,3 / 9$ に比べて大きくなる.これ は越流水深 $(y-W)$ が $2 \mathrm{~cm}$ と小さく粘性と表面張力の 影響が考えられる. $\theta=90^{\circ} \sim 60^{\circ}$ までは， $\alpha=0$ のま ま $\gamma$ を適当に選べばより適合度は高くなる が, $\theta=50^{\circ}$ 以下では,接近流速水頭の効果が大きくな り, $\alpha$ を評価しなければならなくなる.

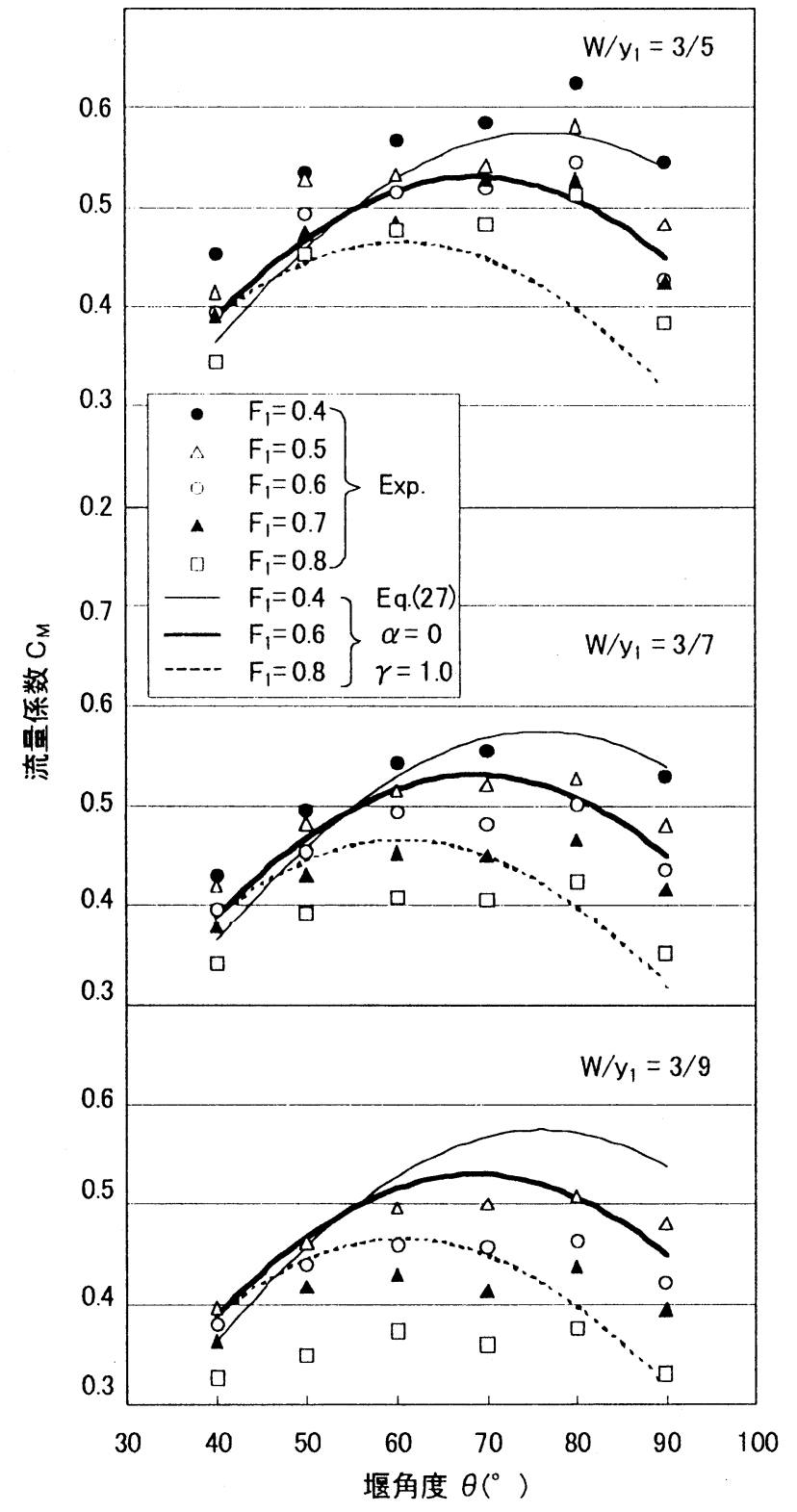

図-5 TypeAにおける堰角度 $\theta$ と流量係数 $C_{M}$ の関係
次に $W / y_{1}=$ const.の条件の下で, $C_{M}$ の $\theta$ による依存 性を $F_{1}$ をパラメーターとして示したものが図-5で ある.図中の記号は $F_{1}=$ const.である.図-5には,式(27) において $\alpha=0, \gamma=1.0$ とし, $F_{1}=0.4,0.6,0.8$ とした時 の計算值である. $\alpha=0, \gamma=1.0$ とした式(27)の適合 性は良いとは言えないが, $C_{M}$ の特性を表してお り, $F_{1}$ が大きくなると $C_{M}$ の極大值を与える堰角度 $\theta$ が $80^{\circ}$ から $60^{\circ}$ へと小さくなることが分かった.こ れらの結果から,同一の堰区間長 $L$ のもとでは,条件 が許せば堰角度を $90^{\circ} よ り 小 さ い ~ 70^{\circ}$ 近くにするこ とで,より高い流出を図ることが可能といえる.

\section{5. 堰角度を有する横越流堰の改良と流量係数}

前章までの実験絬果により,堰角度 $\theta$ を $60^{\circ} \sim 80^{\circ}$ とすれば,Froude数による流量係数の低下の改善がで きることがわかった.しかし,堰角度 $\theta$ を設けると堰 区間において,主水路が急拡部を持つため流れが剥 離する,また低水時には死水域となり流送土砂や塵 芥が堆積するおそれがある.これらの欠点を解消す るために図-6に示すように姮天端から主水路右岸底 面の延長線(1)' -(2)'に向かって斜面を形成するこ とを提案するここをフロントエプロンと名付け

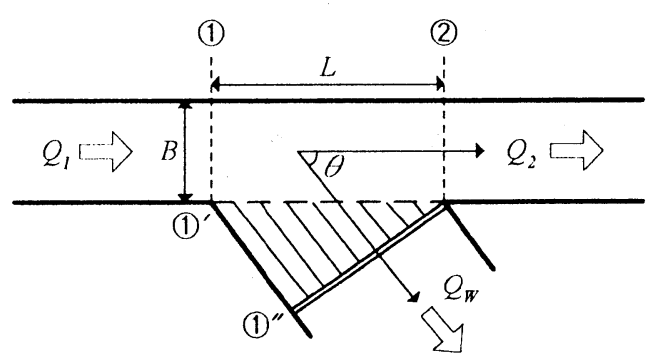

図-6(a)フロントエプロンを持つ横越流㘿TypeF(平面図)

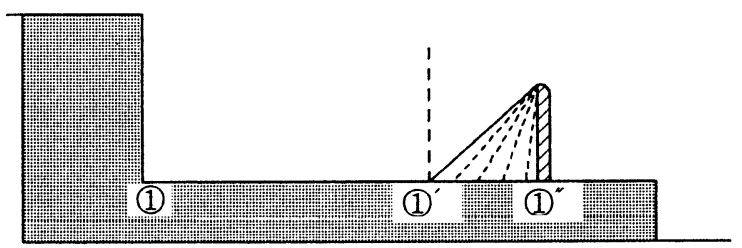

図-6(b) フロントエプロンを持つ横越流堰TypeF (1)-(1)'-(1)" 断面図)

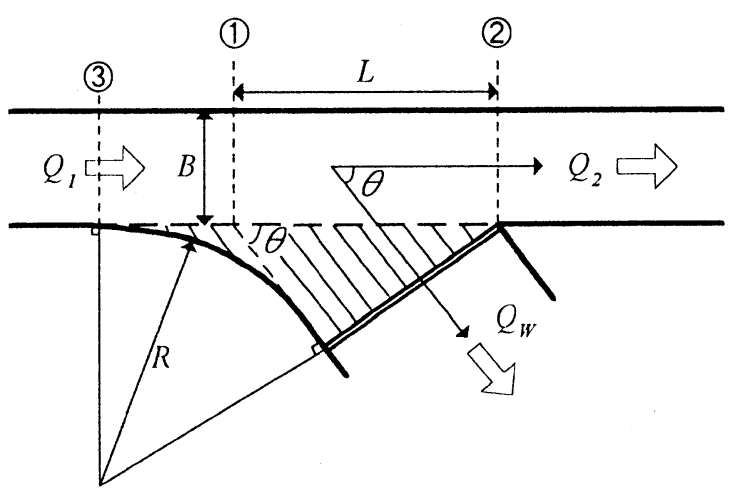

図-7 漸捴フロントエプロンを持つ横越流摼TypeG 
TypeFとする.

さらに,主流の越流堰への流れをスムーズにする ために図-7に示すようにTypeFの堰区間の上流部に 円弧状の漸拡部を取り付けた.これを漸拡フロント エプロンと名付けtypeGとする.実験結果は表-1に示 した.実験結果を図-8に示す。同図はいずれも $\theta=70^{\circ}$ の場合の TypeA,TypcF,TypeGの流量係数 $C_{M}$ と Froude数 $F_{1}$ との関係を示したものである.罒巾の曲 線は式(27)である.ただし， $\alpha$ は図中に示したように Type $\Lambda$ では $\alpha=0$,TypeFでは $\alpha=0.3$,TypeGでは $\alpha=0.55$ とした.

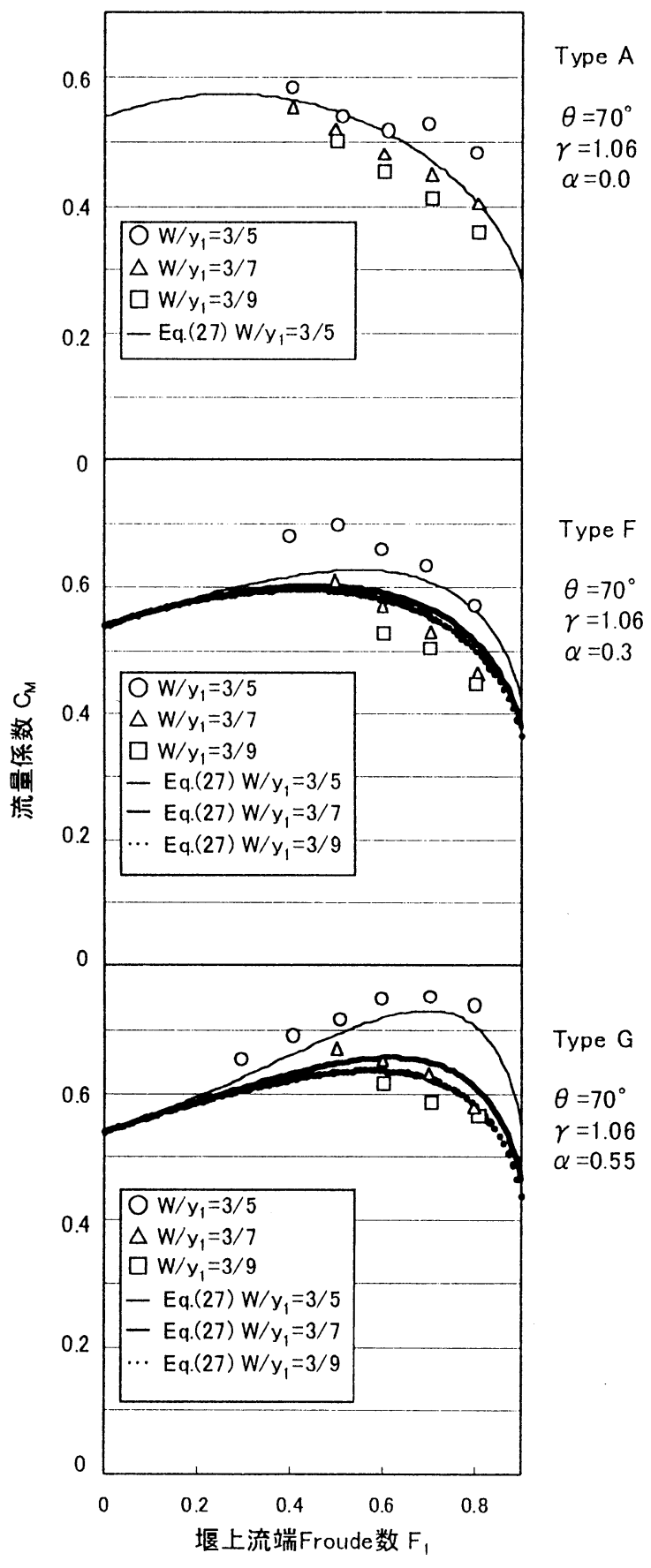

図-8より分かることは以下のことである.

1)フロントエプロンをつけたTypeFではTypeAと比 較して $F_{1}$ の増大による $C_{M}$ の低下が小さい.

2) 漱拡フロントのTypeGでは $F_{1}$ による $C_{M}$ の低下は さらに小さい。

TypeF,Gは主流の流れが揠天端に向かってなめらか になるため,式(27)の $\left[1+\frac{\alpha F_{1}^{2}}{2(1-\eta)}\right]$ で表される接近流 速による効果がより大きく現れて $C_{M}$ の $F_{1}$ による低 下を軽減している。

\section{6.おわりに}

都市河川の洪水ピーク流量を低減するための洪水 調節池の分流亡として横越流堰が多く用いられる。 これは主流の流れを阻害しないこと,メンテナンス フリーであることという大きな特徵を持つが, 主流 のピーク流量時すなわちFroude数の增加に伴って分 流効率が低下するという久点を持っている。これを 改善するために,横越流堰の堰角度 $\theta$ を主流に対し

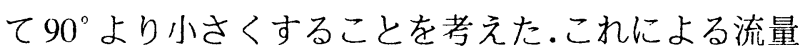
係数 $C_{M}$ の変化を理論と実験により調べた。その結 果, 堰角度 $\theta$ を $60^{\circ} \sim 80^{\circ}$ の間に選ぶとFroude数が大 きいときにも流量係数は低下せず,さらに $\theta=90^{\circ}$ の 通常の獚越流垵に比べて約10\%程度大きくなること が分かった。

この結果を用いて, $\theta=70^{\circ}$ の場合について死水域 解消と流出係数改善のため堰前面に斜面をもつフロ ントエプロン型(TypeA),および濑拡フロントエプロ ン型(TypeG)を考案し, 流量係数 $C_{M}$ のFroude数依存 関係を調べた.その結果TypeGが接近流速水頭の效果 を得て,流量係数がFroude数の高いときにも高い流量 係数 $C_{M} \cong 0.6$ 維持できることが示されたこれら の結果が,都市河川の分流工設計に役立てば幸いで ある。

謝辞：最後に本研究に協力いただいた本学大学院修 了生小野博基氏(現大分県庁)に謝意を表す.

\section{参考文献}

1) De Marchi, G. :Essay on the performance of lateral weirs, L.Energia Elettrica, Milan, Italy, 11, pp.849-860, 1934.

2) Subramanya, K., and Awasthy, S.C. :Spatially varied flow over side weir, Journal of the Hydraulics Division, ASCE, Vol.98, No.1, pp.1-10, 1972.

3) 浦 勝, 小野博基, 秋山壽一郎, 坂本真 : 台形断面 水路に設置された横越流堰の流量式と係数, 水工学 論文集，第42巻，pp.691-696，1998

(1999.9.30受付)

図-8 流最係数 $C_{M}$ とFroude数 $F_{1}$ の関係 